\title{
AN ANTHROPOLOGICAL LINGUISTIC STUDY: LANGUAGE AND GENDER IN EFL CLASSROOM
}

\author{
Anak Agung Putri Maharani \\ Universitas Mahasaraswati Denpasar \\ Email: agungputrimaharani@gmail.com
}

\begin{abstract}
Gender differences are pivotal in EFL (English as A Foreign Language) classroom. The aims of this anthropological linguistic study are to figure out the extent of female and male learners' differences in EFL classroom, the factors which affect the gender differences in the EFL learners' language use, and the effects that learners' gender differences in language use bring to the EFL classroom. Having been designed as a conceptual study, several research findings were scrutinized to answer the research questions. It can be wrapped up that both male and female are distinctive in using English as an international language due to the reasons in communication. Further, it was revealed that multiple factors affect gender differences in using language within the EFL classes; such as: classroom environment, cultural, and social impacts. Finally, the findings definitely convey positive impacts towards the future EFL teaching and learning process.
\end{abstract}

Key words: EFL classroom, gender differences

\begin{abstract}
ABSTRAK
Perbedaan gender (jenis kelamin) sangat penting dalam kelas EFL (English as A Foreign Language). Tujuan dari studi linguistik antropologi ini adalah untuk mengetahui sejauh mana perbedaan siswa perempuan dan laki-laki di kelas $E F L$, faktor-faktor yang mempengaruhi perbedaan gender dalam penggunaan bahasa siswa EFL (khususnya Bahasa Inggris), dan efek yang ditimbulkan dari perbedaan gender siswa dalam menggunakan bahasa di kelas EFL. Dirancang sebagai studi konseptual, beberapa temuan penelitian diteliti untuk menjawab pertanyaan studi ini. Dapat disimpulkan bahwa laki-laki dan perempuan berbeda dalam menggunakan bahasa Inggris sebagai bahasa internasional karena alasan komunikasi. Lebih lanjut, terungkap bahwa banyak faktor mempengaruhi perbedaan gender dalam menggunakan bahasa di kelas EFL; seperti: dampak lingkungan kelas, budaya, dan sosial. Akhirnya, temuan ini jelas membawa dampak positif terhadap proses belajar mengajar EFL di masa depan.
\end{abstract}

Kata Kunci: perbedaan gender, kelas $E F L$

\section{INTRODUCTION}

\section{Rationale}

In this globalization era, English is no longer perceived as a language possessed by limited number of native speakers, rather it is used by speakers from diverse linguistic and cultural background. English is used by many people, and it is treated as an international language in communication. Yee and Chan, (2018) argue that English as a lingua franca (ELF) research has described how English is used among L2 speakers of different backgrounds. Nowadays, English has become the language of business, science, medicine and technology which leads English to be an international language. It is an essential language that everyone must know; perhaps this is one of the strongest reasons why it is studied in most countries' 
schools, institutes, colleges and universities (Ali, 2016).

Using and mastering English successfully will be dependable on various aspects of the language. One of it is gender. It has been mentioned that gender is one of the factors that seem to have a profound effect on using language differently (Mahmud, 2015). Viewed from linguistic anthropology perspective, Jufrizal (2018) states that since gender is socio-cultural contractions in the sense of masculine, feminism or cultural properties towards cultural features, including language, so gender is categorized as linguistically expressed in different ways. $\mathrm{He}$ further argues that all languages are actually influenced by gender because language itself is a cultural product which is not free from cultural properties. Foley (1997) explains that the ideology of gender categories is typically enacted in linguistics practices; indeed, it is through language that the individual cultural understandings of gender categories are learned and the coordination of gender roles achieved.

In relation to linguistic practices, however, significant differences emerge between men and women's speech. Both sexes use the system of speech styles of politeness, but not in identical fashions. The folk linguistic assumptions such as; women are more talkative than men (chattering women), or men interrupt women more, have been among the controversial topics in gender studied(Alami, 2016a). The so-called stereotypes about how women and men use language have been challenged via focusing on different facets of language, for example from different syntactical, phonological and lexical uses of language to aspects of conversation analysis such as topic control, interruption, minimal responses, tag question and hedges and other interactional features.

In relation to EFL context, many factors intervene in the mediocre level of genders; it could be psychological whereby they feel anxious to participate or ask questions; cultural in which males' participation will make their counterparts resemble them to females, or linguistic in which their level in languages is decreased (Hanane, 2019). Sunderland (1992) states that 'Gender in the EFL classroom' is a phrase which used to refer to culturally(though not deterministically) influenced characteristics of each sex; 'sex' to mean whether a person is biologically female or male. Eckert and McConnell-Ginet (2003) point out that gender is not something we are born with, and not something we have, but something we do (West \& Zimmerman 1987) -- something we perform (Butler 1990).

Considering classroom interaction, some studies have been reported the relationship between gender and language learning (Rojas, 2012). These studies, in fact, have contributed to the understanding of gender identities and their influence in learning identities and learning processes. An investigation done by Francis (1998) in a lesson where learners in primary school have to perform a role play about adult occupations. She found out that gender category maintenance is evident in the children's constructions, and that because of this, many children presented gender as oppositional (in opposition and opposite) in their interviews. Moreover, a study which has been conducted by CastañedaPeña (2008b) finds how, during a lesson in a kindergarten while doing "classroom races" around literacy tasks, gender discourses are at stake in the classroom 
and how these discourses are related to the learner identities of a pin down moments in which the assertion of power is manifested in second language practices.

$$
\text { In using language for }
$$

communication, researches on language and gender also reveals the differences between men and women (Mahmud, 2015). It has been mentioned in Mahmud's investigation that women are more polite that men. Hobbs (2003) states that women will use many positive politeness strategies when they talk with the same sex peers. In contrast, in similar circumstances, men do not show this tendency. Another difference is that women are more passive than men. Women tend to show that they are not sure about what they are saying in talking. It is supported by Vanfosses (2001) who mentions that women like using tag questions (It's really cold in here, isn't it?), disclaimers (I may be wrong but...) and questions as directive statements (won't you close the door?).

Based on the aforementioned elucidation, an investigation of language and gender within EFL classroom which involves learners is enticing to be conducted. In EFL classroom, problems caused by men and women's differences in using language may be affecting in which female and male learners interact to each other by using English within their communication. Thus, this study chiefly focuses on that issue in order to figure out to what extent male and female learners use English as an international language differently.

\section{Research Questions}

Based on the research rationale, the research questions can be formulated as follows:
1.1 In EFL classroom, to what extent are female and males learners different?

1.2 What factors are affecting the gender differences in the EFL learners' language use?

1.3 What effects that learners' gender differences in language use bring to the EFL classroom?

\section{RESEARCH METHOD}

Having been designed as a conceptual article, this study investigates the use of English viewed from the gender differences of the learners in EFL classroom. Several previous researches had been reviewed and involved within this study. It was done to answer the threefold research questions posed in this study; 1) to what extent that female and male learners are different in EFL classroom, 2) the factors which affects the gender differences in the EFL learners' language use, and 3) the effects that learners' gender differences in language use bring to the EFL classroom.

\section{FINDING AND DISCUSSION}

This section sheds light on the results of the present study. As what has been mentioned that this study investigates threefold questions which reveal the relationship of the learners' language and gender in EFL classroom. Therefore, the main purpose of the present study is to find out gender differences in using language inside the EFL classes. Further, it also aims to investigate the factors affect the gender differences as well as to depict the effect of learners' gender differences in language use bring to the EFL classroom.

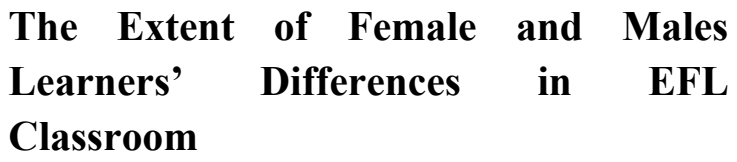


Tymson (1998) classifies differences seen in Table 1:

on men and women in communication as

Table 1. Male and Female's Communication Differences

\begin{tabular}{|c|c|}
\hline Male & Female \\
\hline - $\quad$ Focus on information & - $\quad$ Focus on relationship \\
\hline - Report style of speaking & - $\quad$ Rapport style of speaking \\
\hline - Goal driven & - Process oriented \\
\hline - $\quad$ Single-task approach & - Multi-task approach \\
\hline - $\quad$ Succinct language & - Storytelling style of speech \\
\hline - Working towards a destination & - On a journey \\
\hline - Need to know the answers & - Want to ask the right questions \\
\hline
\end{tabular}

Based on Table 1, the differences between male and females' communication affect expectation of male and females in various fields of life. It can become a critical point of gender inequality which results in different treatment towards both genders. For instance, in terms of leadership, women may be ignored for high position due to their emotional language. A study had shown that the capability of men and women to be a leader may be affected by the notions of emotional women's language, which is not suitable for a leader (Mahmud, 2015).

Furthermore, Lakoff (2004) as cited in Alami (2016) suggests that women's speech typically displays a range of features as follows:

1) Hedges of various types e.g., "well", "y'know", "kinda" and so on.

2) Super polite forms: Women are the experts at using euphemism; they are the repositories of tact. They do not use off-colour or indelicate expression.

3) Tag questions as the statement expressing uncertainty.

4) Question intonation in declarative statements (raising the pitch of voice at the end).
5) Speaking in italics; intonational emphasis equal to underlining words.

6) Empty adjectives such as divine, charming, adorable.

7) Hyper-corrected grammar and pronunciation (English class grammar).

8) Lack of sense of humour: women do not tell jokes well and often do not understand the punch-line of jokes.

9) The use of intensive 'so'

10) Special lexicon: women use more words for things like colours, shopping, while men for sports, car.

These ten differences distinguish women over men. It has been believed that using these devices makes women's language unpleasant. Lakoff goes on to posit that this kind of language renders women's speech tentative, powerless and trivial which disqualifies women from positions of power and authority. In this way language becomes a tool of oppression. Lakoff's concluding remarks were based on two preconceptions: 1) women and men talk differently and 2) differences in women's and men's speech are the result of - and the support of- male dominance.

Furthermore, Coates (1998) finds that story telling', 'hedging', 'questioning', 
'repetition' and 'establishing collaborative floor' as the linguistic strategies women use in talk with friends to establish and maintain close and equal social relationships as well as to minimize social distance. Especially, the use of hedges by women demonstrates the women's strength in relation to their conversational and personal skills. Additionally, hedges can be depicted for a range of positive functions: 1) expressing shades of confidence or doubt, 2) allowing women to be sensitive to others' feelings, 3) assisting women in the search for the right words to express what they mean, and 4) allowing women to avoild playing the expert status.

Taqi et al. (2015) argue that, in the last the last two decades, it has seen various modern and somewhat conflicting theories with regards to learners' gender dynamics in the classroom and its effects on teaching and learning. The patterns of gender are an affective part of the educational construction due to the fact that gender has always been associated with language teaching and learning (Appleby, 2014). Furthermore, Bernat and Lloyd (2007) found that women were more interested in multilingualism than men.

Another study conducted by MeiRong and Hsieh (2007) compare genderrelated differences regarding the use of language for emotion terms. It was found that both men and women used different languages to express their feelings and emotions. Male participants mostly used nouns, in contrast, most of the words said by female participants were adjectives and verbs. Furthermore, Gascoigne (2002) as cited in Shakouri and Saligheh (2012) suggests that males tend to use linguistic devices such as interruptions, directives, and sentence-initial conjunctions. Unlike males, females tend to more heavily rely on questions, justifiers, intensive adverbs, personal pronouns and word-initial adverbs.

\section{The Factors which Affects the Gender} Differences in the EFL Learners' Language Use

First of all, gender and society influence. Ali (2016) states that there is a connection between language and society. An investigation by Xia (2013) found that language and society have a great relationship together which means that changes in the society results in changes in the language. Meanwhile, gender is identified as a social culture (Connell, 2002). Samar and Alibakhshi (2007) in their study figured out that education plays an influential role in gender difference. They further argue that males and females are born into the same world but the society presses them to live in different worlds. Furthermore, it has been proclaimed by Idema and Phalet (2007) that socialization aims at teaching boys and girls to accept their gender roles which means that society has something to do with gender differences.

Second, gender and cultural influence. Cultural background affects the way men and women think, behave and speak. Bernat and Lloyd (2012) conducted a study which explores the effects of gender on EFL learners' beliefs about language learning. It has been figured out that different responses by different genders caused by cultural impacts. Yilmaz (2006) says that culture engages every anthropological aspect in regard to the way of living' of a particular group of people whose ethnic roots descend back to the same ancestors. 


\section{The Effects that Learners' Gender Differences in Language Use Bring to the EFL Classroom}

It is obvious that learners' gender differences in language use impact the EFL classroom. Sunderland (1992) divides the effect of gender differences in the classroom into three cohorts; learning process, teacher-learner interaction, and learner-learner interaction. First of all, the learning process. He states that there are gender differences in language learning styles and strategies. EFL teachers are supposed to provide rich activities that promote learners' styles and strategies in learning. Second, teacher-learner interaction. Sunderland argue that many further ways teachers can treat female and male students differently which includes the selection (who asks/answers a question? who demonstrates?), varying the level of difficulty of questions by gender, and employing double standards for, for example, error identification and treatment, presentation of written work, and acceptable classroom behaviour. These may be neither intentional nor recognized, by either teacher or students. This argument was based on findings in which females talked more than males during the lesson. Third, learner-learner interaction. Sunderland states that this type of interaction is intended to enrich opportunities for classroom communication, spoken which in a long term develop proficiency.

Moreover, Norton and Pavlenko (2002) engage three fields which affected by gender differences such as, curriculum innovation, classroom practices, teachers;' characteristics. In regard to curriculum innovation, they argue that critical educators should organize the curriculum around the needs and lived experiences of learners. Then, classroom practices must be transformative in which the EFL classroom promotes teacher-led discussions, personal storytelling activities, and learners' experiences incorporation with the larger social contexts. Further, the EFL teachers must be proactive and well-prepared to handle the classroom which can maintain a positive dynamic atmosphere in the class. It results in the decentred position of the teachers wherein EFL learners gain greater control of the classroom discussion.

Further, Ali (2016) lists 2 salient pedagogical implications that gender differences bring into the EFL classroom. First, the impact of gender differences on classroom environment. A classroom environment which provides safe and comfortable feeling for every students is required. Second, the impact of gender differences on learning materials. In this case, EFL teachers should provide authentic and up-to-date materials which are similar to the daily life, customs, traditions, literature, art, and life style of the target language speakers.

\section{CONCLUSION}

Gender is a crucial lens through which people view life. In EFL classroom, gender differences in using language are obviously present. Both male and female are different in using language due to the rationale of communication. Women speak a language to demonstrate connection and intimacy while men speak a language to depict status and independence. There are multiple factors which initiate gender differences in using language within the EFL classes; such as: classroom environment, cultural, and social impacts. The findings definitely bring positive 
impacts towards the future EFL teaching and learning process.

\section{REFERENCES}

Alami. (2016a). Approaches to Gender Studies: A Review of Literature. Journal of Applied Linguistics and Language Research, 3(3), 247-256.

Alami, M. (2016b). Approaches to Gender Studies: A Review of Literature. Journal of Applied Linguistics and Language Research, 3(3), 247-256.

Ali, H. O. (2016). Gender Differences in Using Language in the EFL Classes: From Teachers' Views. International Journal of Humanities and Cultural Studies, 2(4).

Chan, J. Y. H. (2018). Gender and attitudes towards English varieties: Implications for teaching English as a global language. In System (Vol. 76, pp. https://doi.org/10.1016/j.system.2018. 04.010

Eckert, P and McConnell-Ginet, S. (2003). Language and Gender Language. Cambridge University Press.

Hanane, B. L. and S. (2019). EFL Teachers' Attitudes on Gender Differences in School Achievements. LLT Journal: A Journal on Language and Language Teaching, 22(2), 156170.

Mahmud, M. (2015). Language and Gender in English Language Teaching. In TEFLIN Journal (Vol. 21, Issue 2, pp. 172-185). https://doi.org/10.15639/teflinjournal. v21i2/172-185

Norton, B., \& Pavlenko, A. (2002). Gender and English Language Learners: Challenges and Possibilities (pp. 1-13).

Rojas, M. X. (2012). Female EFL teachers: shifting and multiple gender and language-learner identities. In Colombian Applied Linguistics Journal (Vol. 14, Issue 1, p. 92). https://doi.org/10.14483/22487085.38 23

Sunderland, J. (1992). Gender in the EFL classroom. In ELT Journal (Vol. 46, Issue 1, pp. 81-91). https://doi.org/10.1093/elt/46.1.81

Taqi, H. A., Al-Darwish, S. H., Akbar, R. S., \& Al-Gharabali, N. A. (2015). Choosing an English Teacher: The Influence of Gender on the Students' Choice of Language Teachers. In English Language Teaching (Vol. 8, Issue 12, p. 182). https://doi.org/10.5539/elt.v8n12p182 